\title{
Olivine and glass chemistry record cycles of plumbing system evolution after summit collapse at Kīlauea Volcano (HI)
}

\author{
K.J.LYNN ${ }^{1 *}$,T.ROSE ${ }^{2}$, D.A.SWANSON ${ }^{3}$ \\ ${ }^{1}$ Department of Earth Sciences, Univ. Delaware, Newark, DE \\ 19716, USA (*correspondence: kjlynn@udel.edu) \\ ${ }^{2}$ National Museum of Natural History, Smithsonian \\ Institution, Washington, D.C. 20560, USA \\ ${ }^{3}$ U.S. Geological Survey, Hilo, HI 96720 USA
}

Volcanic summit collapse significantly impacts crustal plumbing system geometry and can change the dominant magma storage and transport processes recorded by the geochemistry of erupted material [1,2] Caldera collapse has occurred twice in the past 2,500 years at Kîlauea Volcano (Hawaii) and is closely associated with alternating periods dominated by either effusive or explosive eruptions [3]. Here we leverage more than 1,500 olivine forsterite (Fo, $\mathrm{Mg} /(\mathrm{Mg}+\mathrm{Fe}) \times 100)$ and 800 glass $\mathrm{MgO}$ contents of lavas and tephra erupted from 1500 C.E. to present day to characterize the evolution of Kīlauea's crustal reservoir system in context with collapse events. New and previously published analyses delineate three decades- to centuries long periods where progressively evolving olivine and glass compositions are decoupled from inferred changes in magma supply rates. Eruptions that occur after caldera and crater collapse events in 1500, 1790 (inferred), and 1924 have highly heterogeneous olivine and glass populations dominated by $\geq \mathrm{Fo}_{88}$ and up to $11.2 \mathrm{wt} \% \mathrm{MgO}$, respectively. These compositions reflect inefficient mixing of stored and primitive recharge magmas after the disruption of the plumbing system. Fo and $\mathrm{MgO}$ subsequently evolve over decades toward $<\mathrm{Fo}_{82}$ and $<7.0$ wt\% compositions. Low Fo and $\mathrm{MgO}$ reflect efficient mixing of recharge and stored magmas that buffer evolved compositions in a steady-state reservoir system. This evolution occurs three times over $16^{\text {th }}, 18^{\text {th }}$, and early $20^{\text {th }}$ century cycles, each beginning with a caldera forming or explosive crater collapse event. Preliminary analyses of Kulanaokuaiki Tephra (400-1000 C.E., within the Uwēkahuna Ash explosive period) yield $\geq \mathrm{Fo}_{88}$ olivine and glass $\mathrm{MgO}$ as high as $12 \mathrm{wt} \%$. Thus, the composition of explosive vs. effusive period erupted material can be used to investigate summit collapse, magmatic processes, and the geometry of the crustal plumbing system.

[1] Gavrilenko et al. (2016) Bull Volc, 78, 47. [2] Corbi et al. (2015) EPSL, 431, 287-293. [3] Swanson et al. (2014) Geology, 42, 631-634. 